\title{
Adaptation of Academic Success Inventory Scale for College Students to Turkish: Validity and Reliability Study
}

\author{
DOI: $10.26466 /$ opus. 879645
}

\author{
Kenan Orçanl1 * Mustafa Bekmezci ** Hasan Boztoprak *** \\ * Asst. Prof. Dr, Toros University, Department of EASS, Business, Mersin \\ E-Posta: kenanorcanli@gmail.com \\ ORCID: 0000-0001-5716-4004 \\ ** Prof. Dr., Toros University, Department of EASS, Business, Mersin \\ E-Posta: mustafa.bekmezci@toros.edu.tr ORCID: 0000-0002-1206-690X \\ * Asst. Prof. Dr, Beykent University, Department of EASS, Business, İstanbul \\ E-Posta: hasanboztoprak@beykent.edu.tr \\ ORCID: $\underline{0000-0002-7560-367 X}$
}

\begin{abstract}
The approach that "One can not manage without measuring" has brought up the idea that intangible concepts should also be measured into the agenda. Measurement of intangible concepts, in other words defining them in numerical terms is quite difficult and different methods are proposed for measurement of these concepts. Measuring academic success is also considered in this context. In national literature, academic success is generally considered as class passing grade or graduation grade. However, the expression of academic success with the grades taken from the exams does not fully reflect the fact. Because other factors affecting the grades obtained from exams are ignored. Therefore, it is considered that there is a need for a scale that will help both advisors and students and to measure academic success more clearly. With the Turkish adaptation of the Academic Success Inventory for College Students (ASICS), which was developed by Prevatt et al. (2011) to fill this gap in national literature with the aim to measure the academic success of university students as being used successfully in many countries, validity and reliability study has been done. The data were collected by convenience sampling method from university students studying in Mersin between the dates June 18 and July 18, 2020. The survey was created with Google Form and the survey link was shared with the social communication network application. Data analysis was done with R programming language, and SPSS and AMOS sofwares. Explanatory and confirmatory factor analysis were used in the analyses. Cronbach's alpha value of the total scale is 0.937. The values of goodness of fit in the 1st level multifactorial structure were calculated as RMSEA: 0.075, CFI: 0.998, TLI: 0.978, NFI: 0.988 and $\chi 2 / d f: 2.220$. Calculated values are compatible with reference values. It was evaluated that Academic Success Inventory Scale could also be used in Turkey and more accurate results could be obtained on academic success.
\end{abstract}

Keywords:

Academic Success, The Academic Success Inventory for College

Students, ASICS, scale, reliability, validity. 


\title{
Üniversite Öğrencileri İçin Akademik Başarı Envanteri Ölçeği'nin Türkçeye Uyarlanması: Geçerlik ve Güvenirlik Çalışması
}

\begin{abstract}
Öz
“Ölçmeden yönetemezsin" yaklaşımı, soyut kavramların da ölçülmesi gerektiği düşüncesini gündeme taşımıştır. Soyut kavramların ölçülmesi, diğer bir anlatımla sayısal olarak ifade edilmesi oldukça güçtür ve bu kavramların ölçülmesi için farkl yöntemler önerilmektedir. Akademik başarmın ölçülmesi de bu kapsamda değerlendirilmektedir. Ulusal yazında akademik başarl, genellikle sinıf geçme notu veya mezuniyet derecesi olarak ele alınmaktadır. Ancak akademik başarının sinavlardan alınan notlarla ifade edilmesi gerçeği tam olarak yansıtmamaktadır. Çünkü sinavlardan alınan notları etkileyen diğer unsurlar göz ardı edilmektedir. Dolayısıyla hem danışmanlara hem de öğrencilere yardımcı olacak, akademik başarıyı daha net ölçen bir ölçeğe ihtiyaç olduğu değerlendirilmişstir. Ulusal yazındaki bu eksikliği gidermek için Prevatt vd. (2011) tarafından üniversite öğrencilerinin akademik başarısını ölçmek için geliştirilen ve pek çok ülkede başarıla kullanılan Akademik Başarı Envanteri Ölçeği (Academic Success Inventory (ASICS))'nin Türkçe uyarlaması ile geçerlik ve güvenirlik çalışması yapılmıştır. Veriler 18 Haziran-18 Temmuz 2020 tarihleri arasında, Mersin'de öğrenim gören üniversite öğrencilerinden, kolayda örnekleme yöntemi ile toplanmıştır. Anket, Google Form ile oluşturulmuş, anket linki Whats App uygulaması ile paylaşılmışıtır. Verilerin analizi R programlama dili, SPSS ve AMOS paket programları ile yapılmıştır. Analizlerde açıklayıcı ve doğrulayıcı faktör analizi ile korelasyon analizi kullanılmıştır. Ölçeğin Cronbach alfa değeri 0.937, 1'inci düzey çok faktörlü yapıda uyum iyiliği değerleri; RMSEA: 0.075, CFI: 0.998, TLI: 0.978, NFI: 0.988 ve х2/df: 2.220 olarak hesaplanmıştır. Hesaplanan değerler referans değerleri ile uyumludur. Akademik Başarı Envanteri Ölçeği'nin Türkiye'de de kullanılabileceği ve akademik başarı konusunda daha doğru sonuçlar elde edilebileceği değerlendirilmiştir.
\end{abstract}

Anahtar Kelimeler: Akademik Başarı, Akademik Başarı Envanter Ölçeği, ASICS, Ölçek, Güvenirlik, Geçerlik 


\section{Introduction}

Universities are important education institutions that improve intellectual level of people, enable gaining of scientific thinking ethics, and develop qualified labor force. Universities affect society with respect to academic, social, and cultural aspects and they become the pioneer for change and development (Saygin and Bekmezci, 2019, p. 109). When it is evaluated in this context, it is seen that high academic success of university students is of great importance in terms of both individual and professional qualification of graduates. On the other hand, universities also attach importance to the academic success of their students in terms of revealing the quality of the university. University students' success is generally tried to be estimated by using demographic and academic variables (Alay and Koçak, 2003; Alver, 2005; Kadim and Şişman, 2017). However, it is stated that these variables are insufficient to explain academic achievement (Pritchard and Wilson, 2003; Prevatt et al., 2011). Hence, although graduation from university makes a big difference in terms of people's employment, income and respect in society, a total of 1 million 115 thousand and 530 students have leaved university or frozen their registration in the last 5 years according to official figures in Turkey, whereas within 2013-2014 academic year, their number was 135 thousand and 137; within 2014-2015 academic year, their number was 161 thousand and 193; within 2015-2016 period their number was 197 thousand and 482; within 2016-2017 academic year, their number was 212 thousand and 770; within 2017-2018 academic year, their number was 408 thousand and 948 students. (Sozcu, 2019). Considering the success of the students in the university entrance exam as a result of their efforts to enter the university, it can be said that this situation is a significant loss for both students and the country. Necessary measures can be taken for students to stay at the university and to be successful if the reasons for leaving the university or freezing enrollment are determined.

Academic achievement of university students in Turkey is usually measured by average test scores or graduation rate. However, the exam grade or graduation grade is not sufficient to evaluate academic success. There are many factors affecting the exam grade or graduation grade. The purpose of this study is to adapt Academic Success Inventory for College Students (ASICS) developed by Prevatt et al (2011) for university students with the 
aim to measure academic success of university students in a more healthier way and to prevent failure of students having probability to fail, into Turkish and to gain it to Turkish literature.

\section{Academic success and its measurement}

Education is the building block of both individual and social development. As a matter of fact, human beings want to grasp, understand and explain concrete and abstract facts and events related to themselves and in their environment, and they create disciplinary knowledge within the framework of positivist understanding of science. It is important to use knowledge in practical life as well as the production of specific knowledge. In this context, educational institutions play a primary role in the systematic transfer of knowledge to certain segments of society. Effective and efficient transfer of knowledge affects both the studying person and the entire society. In this context, the extent to which students acquire the information transferred becomes an important issue. This situation is important in terms of ensuring both individual success and institutional effectiveness. This issue is discussed and measured in the literature within the framework of academic achievement.

In the researches about the academic success of students, academic achievement is generally evaluated on the grade point average (Alay and Koçak, 2003; Alver, 2005; Chamorro-Premuzic and Furnham, 2003; Kadim and Şişman, 2017; Rana and Mahmood, 2010; Treffers-Daller and Milton, 2013; Vaez and Laflamme, 2008; York et al., 2015; Zwick and Sklar, 2005). Although this application measuring the student's current knowledge and previous gains, is easy and useful, it is also known that there are different variables that have indirect effects on academic success. As a matter of fact, this assessment which is expressed as traditional success criteria, explains $25 \%$ of the variance in the overall grade average of the university (Festa-Dreher, 2012 , p. 2). Other variables affecting academic achievement include discipline, family, groups of friends, self-confidence, school environment, extracurricular activities (Prevatt et al., 2011, p. 26). As a result of the meta-analysis on 109 studies, Robbins et al. (2004) found the psycho-social and work skills factors that determine academic achievement being success motivation, academic goals, institutional commitment, perceived social support, 
social participation, academic self-efficacy, general self-perception, academic ability and contextual effects. They determined that the best predictors for GPA are academic self-efficacy and motivation for achievement. These factors identified by Robbins et al. (2004) actually refer to non-traditional assessment factors related to academic achievement other than traditional and standardized assessments. Most of these unconventional evaluations are based on theories such as self-determination theory, cognitive evaluation theory, achievement goal theory and self-regulation theory (Festa-Dreher, 2012, p. 9-11).

Self-determination theory asserts that people have a desire to expand and develop their interests (Festa-Dreher, 2012, p. 9). Self-determination theory focuses on one's interest in learning and enhancing the value of education, self-confidence and effectiveness. Cognitive assessment theory focuses solely on self-motivation. It acknowledges that outcomes such as rewards, evaluations or feedback have a special meaning or functional significance that predicts their effect on intrinsic motivation. This is largely related to the effect of such results on autonomy or competence (Ryan and Deci, 2017, p. 123). Cognitive assessment theory classifies innate human needs into three categories as competence, relationship and autonomy (Deci et al., 1991, p. 327). competence refers to one's sense of skill or ability rather than actual success; autonomy is an internal locus of control from which behavior is initiated spontaneously; relationship refers to making meaningful connections with other individuals. It is stated that facilitating people's competence, autonomy and relationship needs in education will create more subjective well-being, better exam results, higher grade point average and more motivation for the desired career in the future (Sheldon and Krieger, 2007). Success is the state of achieving a goal defined positively at the individual level, and achieving a desired goal (Demir and Acar, 2020, p. 35). Achievement goals are specific and are related to what a student hopes to achieve academically (Festa-Dreher, 2012, p. 14). Goals and a person's interest affect academic performance (Daniels et al., 2009; Harackiewicz et al., 2002). Self-control is a process that involves a person's ability to know, monitor his behavior and motivation in order to achieve his goal (Pintrich, 1999). Students with self-control, approach learning in a systematic, cont- 
rolled and planned manner, and take responsibility for learning (Zimmerman, 1990). Academic performance improves as self-control increases (Nota et al, 2004).

Prevatt et al (2011) who stated that scales have been determined as focusing on different aspects of academic success of university students such as their life stress (Gadzella, 1994), motivation (Vallerand et al, 1992), learning and working strategies (Weinstein and Palmer, 2002; Prevatt et al, 2006), university attendance (Davidson et al, 2009) but that a reliable and valid scale measuring different aspects of academic success has not been developed, have developed Academic Success Inventory for College Students (ASICS) for university students. ASICS was developed to identify students who are likely to fail, and it is a comprehensive scale that determines the strengths and weaknesses of these students in order to prevent their failure and helps to make appropriate interventions in this context and is easily applicable (Prevatt et al., 2011, p. 27). The ASICS scale consists of 10 subdimensions and 50 questions. The sub-dimensions of the scale are as follows (Prevatt et al, 2011, p. 27):

General Academic Skills (12 items) - a combination of effort expended, study skill and self-organizational strategies.

Internal Motivation/Confidence (8 items) - belief in one's ability to perform well academically, as well as satisfaction and challenge associated with performance.

Perceived Instructor Efficacy (5 items) - perception of the ability of the instructor to hold the attention of the student, organize, teach, and assess the progress of the student.

Concentration (4 items) - ability to concentrate and pay close mental attention.

External Motivation/Future (4 items) - an awareness of the future relevance or importance of the class, with an emphasis on external job-related issues.

Socializing (4 items) - appropriate levels of socializing or drinking such that one's academic performance is not hindered.

Career Decidedness (4 items) - progress towards and certainty of one's decision about a career goal.

Lack of Anxiety ( 3 items) - lack of anxiety or nervousness with regard to studying or test taking. 
Personal Adjustment (3 items) - lack of personal issues that detract from one's ability to perform academically.

External Motivation/Current (3 items) - motivation to perform, with an emphasis or current external factors such as grades, parents or approval of others.

In the researches conducted in relation to academic success inventory, Cronbach alpha values of sub-dimensions of scale were reported by Prevatt et al (2011) as 0.62-0.93; by Ashkzari et al (2018) as 0.74-0.92; by Sadeghi-Gandomani and Adib-Hajbaghery (2018) as 0.51-0.75; by Howard et al (2019) as 0.52-0.90.

\section{Method}

In this chapter; information is given about population and sample, data collection method and tools, and analysis methods used.

\section{Participants}

The data were collected from undergraduate university students studying in Mersin between June 18 and July 18, 2020. Therefore, the main body of the study consists of university students studying at undergraduate level in Mersin. It was determined that there were 23.107 undergraduates studying in Mersin at the time of the survey (YOK ATLAS, 2020). The minimum sample size was calculated with the formula (1) (Eygü and Güllüce, 2017, p. 276).

$$
\mathrm{n}=\frac{\mathrm{NpqZ}^{2}}{(\mathrm{~N}-1) \mathrm{d}^{2}+\mathrm{pqZ}^{2}}=\frac{23107 * 0,5 * 0,5 * 1,96 * 1,96}{(23.106 * 0,05 * 0,05)+(0,5 * 0,5 * 1,96 * 1,96)}=380
$$

The convenience sampling method was used to collect the data. In the literature, it is stated that when the data is needed in a short time and with the least cost, the data can be collected with the non-probabilistic sampling method (Eygü and Kılınç, 2019, p. 1027).

The questionnaire is consisting of two parts: (1) Demographic information, (2) Academic Success Inventory for College Students. We communicated online survey form via socal networks and obtained a data set consisting 403 respondents. Then we analyzed the questionnaires, 21 respondents 
were not found suitable for analysis, the remaining 382 respondents were analyzed.

In the analyzes, the data were divided into two groups (1st Sample: 182 surveys and 2nd Sample: 200 surveys). The first sample data were used in the explanatory factor analysis to control the construct validity of the scale, and the second sample data were used in the analyzes conducted within the scope of the confirmatory factor analysis and reliability studies (Eskioğlu, 2017, p. 75). The demographic information of the participants for both samples are given in Table- 1 and Table-2.

Table 1. Demographic information relating with 1th sample

\begin{tabular}{|c|c|c|c|c|c|c|c|}
\hline \multicolumn{2}{|c|}{ Variable } & $\mathrm{f}$ & $\%$ & & Variable & $\mathrm{f}$ & $\%$ \\
\hline Gender & $\begin{array}{l}\text { Female } \\
\text { Male } \\
\text { Total }\end{array}$ & $\begin{array}{c}68 \\
114 \\
\mathbf{1 8 2}\end{array}$ & $\begin{array}{c}68 \\
114 \\
100\end{array}$ & Class & $\begin{array}{l}\text { Preparatory } \\
\text { 1. Class } \\
\text { 2. Class } \\
\text { 3. Class } \\
\text { 4. Class } \\
\text { 5. Class } \\
\text { 6. Class } \\
\text { Total }\end{array}$ & $\begin{array}{c}22 \\
57 \\
46 \\
39 \\
14 \\
2 \\
2 \\
\mathbf{1 8 2}\end{array}$ & $\begin{array}{c}12 \\
31 \\
25 \\
21 \\
8 \\
1 \\
1 \\
100\end{array}$ \\
\hline $\begin{array}{c}\text { From what } \\
\text { field he } \\
\text { entered the } \\
\text { university }\end{array}$ & $\begin{array}{l}\text { Digital } \\
\text { Verbal } \\
\text { Equal weight } \\
\text { Foreign language } \\
\text { Private skills } \\
\text { Total }\end{array}$ & $\begin{array}{c}46 \\
69 \\
54 \\
11 \\
2 \\
182\end{array}$ & $\begin{array}{c}25 \\
38 \\
30 \\
6 \\
1 \\
\mathbf{1 0 0}\end{array}$ & Yaş & $\begin{array}{l}17-19 \\
20-22 \\
23-25 \\
26-28 \\
28 \text { and above } \\
\text { Total }\end{array}$ & $\begin{array}{c}20 \\
64 \\
46 \\
41 \\
11 \\
182\end{array}$ & $\begin{array}{c}11 \\
35 \\
25 \\
23 \\
6 \\
100\end{array}$ \\
\hline
\end{tabular}

Table 2. Demographic information relating with 2 nd sample

\begin{tabular}{|c|c|c|c|c|c|c|c|}
\hline \multicolumn{2}{|c|}{ Variable } & $\mathrm{f}$ & $\%$ & & Variable & $\mathrm{f}$ & $\%$ \\
\hline Gender & $\begin{array}{l}\text { Female } \\
\text { Male } \\
\text { Total }\end{array}$ & $\begin{array}{c}76 \\
124 \\
\mathbf{2 0 0}\end{array}$ & $\begin{array}{c}38 \\
62 \\
100\end{array}$ & Class & $\begin{array}{l}\text { Preparatory } \\
\text { 1. Class } \\
\text { 2. Class } \\
\text { 3. Class } \\
\text { 4. Class } \\
\text { 5. Class } \\
\text { 6. Class } \\
\text { Total }\end{array}$ & $\begin{array}{c}27 \\
60 \\
50 \\
45 \\
14 \\
2 \\
2 \\
200\end{array}$ & $\begin{array}{c}14 \\
30 \\
25 \\
22 \\
7 \\
1 \\
1 \\
100\end{array}$ \\
\hline $\begin{array}{l}\text { From what } \\
\text { field he } \\
\text { entered the } \\
\text { university }\end{array}$ & $\begin{array}{l}\text { Digital } \\
\text { Verbal } \\
\text { Equal weight } \\
\text { Foreign } \\
\text { language } \\
\text { Private skills } \\
\text { Total }\end{array}$ & $\begin{array}{c}60 \\
69 \\
54 \\
15 \\
2 \\
200\end{array}$ & $\begin{array}{c}30 \\
35 \\
27 \\
7 \\
1 \\
\mathbf{1 0 0}\end{array}$ & Age & $\begin{array}{l}17-19 \\
20-22 \\
23-25 \\
26-28 \\
28 \text { and above } \\
\text { Total }\end{array}$ & $\begin{array}{c}28 \\
60 \\
50 \\
51 \\
11 \\
200\end{array}$ & $\begin{array}{c}14 \\
30 \\
25 \\
26 \\
5 \\
100\end{array}$ \\
\hline
\end{tabular}




\section{Academic Success Inventory Scale}

Academic Success Inventory Scale for College Students has been developed by Prevatt et al (2011) with the aim to measure academic success of university students in general terms. The scale consists of 10 sub-dimensions ( 1 . General Academic Skills, 2. Internal Motivation/Confidence, 3. Perceived Instructor Efficacy, 4. Concentration, 5. External Motivation/Future, 6. Socializing, 7. Career Decidedness, 8. Lack of Anxiety, 9. Personal Adjustment, 10. External Motivation/Current) and 50 questions. The answers in the scale were taken with 7-point Likert (poles from ' 1 ' (strongly disagree) to ' 7 ' (strongly agree)). Cronbach's alpha coefficient of the scale was reported to be 0.93 for the 1st subscale, 0.86 for the 2 nd subscale, 0.92 for the 3 rd subscale, 0.87 for the 4 th subscale, 0.88 for the 5 th subscale, 0.84 for the 6 th subscale, 0.87 for the seventh subscale, 0.77 for the 8 th subscale, 0.86 for the 9 th subscale, and 0.62 for the 10 th subscale. The total variance explained is $64 \%$. It was stated that the unification and dissociation validity of the scale was also provided.

\section{Tools Used During Data Analysis}

In this study, SPSS and AMOS package programs and R programming language have been used. With SPSS package program, explanatory factor analysis and confidence analysis were made and with AMOS package program, confirmatory factor analysis was made and multi-variable normal distribution of data were controlled with $\mathrm{R}$ programming language.

\section{Results}

In this section, some calculations made based on expert opinion within the content and logical validity of the scale, results of explanatory and confirmatory factor analysis made within the scope of construct validity and statistical values obtained within the scope of reliability study are included.

\section{Adaptation of scale to Turkish}

The method suggested by Brislin (1970) was used in the adaptation of the Academic Achievement Inventory to Turkish. First of all, a group of five 
people having expertise is English, translated the scale from English to Turkish separately and created a translation form. On the translation form created afterwards, two people specialized in Turkish language have combined translations with people specialized in English language and they were prepared by ensuring scale language equivalent values. In order to control whether the items of the scale fully meet the purpose specified in Turkish, the English version and the Turkish version of the scale were applied separately to two sample groups of 25 people and the relationship status was checked. Subsequently, the scale was translated from Turkish to English, it was checked whether there was any loss of meaning.

\section{Content And Logical Validity Of Scale}

Expert opinion was consulted for the content and logical validity of the Academic Success Inventory Scale. The scale items were shown to an expert group of 20 people, and these people were asked to evaluate each item as "necessary", "necessary but insufficient" and "insufficient" within the scope of the purpose. The Content Validity Ratio (CVR) and Content Validity Index (CVI) required for the evaluation of expert opinions and scale items are given in Table 3.

Table 3. Expert Opinions on the Items of the Academic Success Scale

\begin{tabular}{|c|c|c|c|c|c|}
\hline Subscale and Items & $\mathbf{N}^{*}$ & $\mathbf{N ~ I}^{*}$ & $\mathbf{I}^{*}$ & CVR & CVI \\
\hline \multicolumn{6}{|l|}{ General Academic Skills (GAS) } \\
\hline $\begin{array}{l}\text { I studied the correct material when preparing for tests in this } \\
\text { class (GAS1) }\end{array}$ & $\mathrm{s}_{19}$ & 1 & - & 0.80 & \multirow{12}{*}{0.80} \\
\hline I worked hard to prove I could get a good grade (GAS2) & 19 & 1 & - & 0.80 & \\
\hline I tried everything I could to do well in this class (GAS3) & 19 & 1 & - & 0.80 & \\
\hline I worked really hard in this class (GAS4) & 19 & 1 & - & 0.80 & \\
\hline I kept on a good study schedule in this class (GAS5) & 18 & 2 & - & 0.60 & \\
\hline $\begin{array}{l}\text { I worked hard in this class because I wanted to understand the } \\
\text { material (GAS6) }\end{array}$ & $e_{18}$ & 2 & - & 0.60 & \\
\hline I studied a lot for this class (GAS7) & 19 & 1 & - & 0.80 & \\
\hline $\begin{array}{l}\text { I think I used good study skills when working in this class } \\
\text { (GAS8) }\end{array}$ & & 1 & - & 0.80 & \\
\hline $\begin{array}{l}\text { I made good use of tools such as planners, calendars and organ } \\
\text { izers in this class (GAS9) }\end{array}$ & 19 & 1 & - & 0.80 & \\
\hline I used a goal setting as a strategy in this class. (GAS10) & 20 & - & - & 1.00 & \\
\hline I was good at setting specific homework goals (GAS11) & 19 & 1 & - & 0.80 & \\
\hline I was well organized (GAS12) & 20 & - & - & 1.00 & \\
\hline
\end{tabular}




\begin{tabular}{|c|c|c|c|c|c|}
\hline Subscale and Items & $\mathbf{N}^{*}$ & $\mathrm{~N} \mathrm{I}^{*}$ & $I^{*}$ & CVR & CVI \\
\hline \multicolumn{6}{|l|}{ Internal Motivation/Confidence (IM) } \\
\hline I got satisfaction from learning new material in this class (IM1) & 20 & - & - & 1.00 & \multirow{8}{*}{0.80} \\
\hline $\begin{array}{l}\text { I enjoyed the challenge of just learning for learning's sake in this } \\
\text { class (IM2) }\end{array}$ & 19 & 1 & - & 0.80 & \\
\hline $\begin{array}{l}\text { I felt confident I could understand even the most difficult mate- } \\
\text { rial in this class (IM3) }\end{array}$ & $2-19$ & 1 & - & 0.80 & \\
\hline I was pretty sure I could make an A or B in this class (IM4) & 19 & 1 & - & 0.80 & \\
\hline I knew that if I worked hard, I could do well in this class (IM5) & 19 & 1 & - & 0.80 & \\
\hline I worried a lot about failing this class (IM6) & 19 & 1 & - & 0.80 & \\
\hline I was pretty sure I would get a good grade in this class (IM7) & 18 & 2 & - & 0.60 & \\
\hline I felt pretty confident in my skills and abilities in this class (IM8) & 19 & 1 & - & 0.80 & \\
\hline \multicolumn{5}{|l|}{ Perceived Instructor Efficacy (PIE) } & \multirow{6}{*}{0.80} \\
\hline I was disappointed with the quality of the teaching (PIE1) & 19 & 1 & - & 0.80 & \\
\hline I did poorly because the instructor was not effective (PIE2) & 19 & 1 & - & 0.80 & \\
\hline I would have done better if my instructor were better (PIE3) & 19 & 1 & - & 0.80 & \\
\hline The instructor in this class really motivated me to do well (PIE4) & 19 & 1 & - & 0.80 & \\
\hline $\begin{array}{l}\text { Anything I learned, I learned on my own. The instructor in this } \\
\text { class was not a good teacher (PIE5) }\end{array}$ & $s_{19}$ & 1 & - & 0.80 & \\
\hline \multicolumn{6}{|l|}{ Concentration $(\mathrm{C})$} \\
\hline It was easy to keep my mind from wandering in this class (C1) & 20 & - & - & 1.00 & \multirow{4}{*}{0.85} \\
\hline I had an easy time concentrating in this class (C2) & 19 & 1 & - & 0.80 & \\
\hline I had a hard time concentrating in this class (C3) & 19 & 1 & - & 0.80 & \\
\hline I got easily distracted in this class (C4) & 19 & 1 & - & 0.80 & \\
\hline \multicolumn{6}{|l|}{ External Motivation/Future (EM) } \\
\hline I needed to do well in this class to get a good job later on (EM1) & 19 & 1 & - & 0.80 & \multirow{4}{*}{-0.85} \\
\hline This class will be very useful to me in my career (EM2) & 18 & 2 & - & 0.60 & \\
\hline This class is important to my future success (EM3) & 20 & - & - & 1.00 & \\
\hline $\begin{array}{l}\text { I think in the future I will really use the material I learned in this } \\
\text { class (EM4) }\end{array}$ & $\mathrm{s}_{20}$ & - & - & 1.00 & \\
\hline \multicolumn{5}{|l|}{ Socializing (S) } & \multirow{5}{*}{0.80} \\
\hline Sometimes I partied when I should have been studying (S1) & 19 & 1 & - & 0.80 & \\
\hline My grades suffered because of my active social life (S2) & 19 & 1 & - & 0.80 & \\
\hline $\begin{array}{l}\text { I got behind in this class because I spent too much time partying } \\
\text { or hanging out with my friends (S3) }\end{array}$ & & 1 & - & 0.80 & \\
\hline $\begin{array}{l}\text { Sometimes my drinking behavior interfered with my studying } \\
\text { (S4) }\end{array}$ & & 1 & - & 0.80 & \\
\hline \multicolumn{5}{|l|}{ Career Decidedness $(\mathrm{CD})$} & \multirow{5}{*}{-0.85} \\
\hline $\begin{array}{l}\text { I am certain about what occupation I want after I graduate } \\
\text { (CD1) }\end{array}$ & $e_{18}$ & 2 & - & 0.60 & \\
\hline I know what I want to do after I graduate (CD2) & 20 & - & - & 1.00 & \\
\hline I am having a hard time choosing a major (CD3) & 20 & - & - & 1.00 & \\
\hline I am certain that my major is a good fit for me (CD4) & 19 & 1 & - & 0.80 & \\
\hline \multicolumn{5}{|l|}{ Lack of Anxiety (LA) } & \multirow{3}{*}{0.87} \\
\hline I was nervous for tests even when I was well prepared (LA1) & 19 & 1 & - & 0.80 & \\
\hline Studying for this class made me anxious (LA2) & 20 & - & - & 1.00 & \\
\hline
\end{tabular}




\begin{tabular}{|c|c|c|c|c|c|}
\hline Subscale and Items & $\mathbf{N}^{*}$ & $\mathrm{~N} \mathrm{I}^{*}$ & $\mathbf{I}^{*}$ & CVR & CVI \\
\hline I got anxious when taking tests in this class (LA3) & 19 & 1 & - & 0.80 & \\
\hline \multicolumn{6}{|l|}{ Personal Adjustment (PA) } \\
\hline Personal problems kept me from doing well in this class (PA1) & 20 & - & - & 1.00 & \\
\hline $\begin{array}{l}\text { I would have done much better in this class if I didn't have to } \\
\text { deal with other problems in my life (PA2) }\end{array}$ & & 1 & - & 0.80 & \multirow[t]{2}{*}{080} \\
\hline $\begin{array}{l}\text { I had some personal difficulties that affected my performance in } \\
\text { this class (PA3) }\end{array}$ & $n$ & 2 & - & 0.60 & \\
\hline \multicolumn{5}{|l|}{ External Motivation/Current (EMC) } & \multirow{5}{*}{-080} \\
\hline $\begin{array}{l}\text { It was important to get a good grade in this class for external rea } \\
\text { sons (my parents, A scholarship, university regulations) (EMC1 }\end{array}$ & 19 & 1 & - & 0.80 & \\
\hline $\begin{array}{l}\text { I worked hard in this class because I wanted others to think I was } \\
\text { smart (EMC2) }\end{array}$ & 19 & 1 & - & 0.80 & \\
\hline I needed good grades in this class to keep up my GPA (EMC3) & 19 & 1 & - & 0.80 & \\
\hline * N: Necessary, N/I: Necessary but Insufficient, I: Insufficient & & & & & \\
\hline
\end{tabular}

According to the values in Table 3, the Content Validity Ratio (CVR) and Content Validity Index (CVI) values were calculated to decide which items should remain in the scale or which items should be excluded from the scale. CVR is one less $((\mathrm{N} /(\mathrm{n} / 2)-1)$ obtained with half of the total number of experts (n) of the number of experts $(\mathrm{G})$ marking the expression "Necessary". CVI is the arithmetic mean of the CVR values of the items remaining in the scale as a result of the statistical evaluation. In the evaluation made according to the expert group of 20 people at 0.05 significance level, the CVR value should be above the critical value of 0.42 and the CVI values should be above the critical value of 0.67 (Alpar, 2012, p. 415). In this context, it was observed that the scope and logical validity of the scale was achieved with the values obtained in the calculation made according to the CVR and CVI values of the scale items in Table 3, and there was no need to remove any scale item.

\section{Construct Validity of the Scale and Explanatory and Confirmatory Factor Analysis}

Explanatory factor analysis was performed in order to ensure the content validity of the data and to determine the measured dimensions correctly (Can, 2018; Seçer, 2015; Tavşanc1l, 2014). At this stage, Kaiser-Meyer-Olkin (KMO) and Barlett's tests were used to decide whether the data were suitable for explanatory factor analysis. By using Kaiser-Meyer-Olkin (KMO) 
and Barlett's test, the sample is tested to be of suitable size and quality for exploratory factor analysis (Pallant, 2017; Tabachnick and Fidell, 2001). In the explanatory factor analysis, the lowest value that item factor loads should take is accepted as " 0.30 " and application should be made on factors with eigenvalues greater than "1" (Alyılmaz and Polatcan, 2018; Neale and Liebert, 1980; Pallant, 2017; Tabachnick and Fidel, 2001). For this reason, items with item factor loads below 0.30 and factors with eigenvalues lower than 1 were not evaluated as a result of the explanatory factor analysis.

After the explanatory factor analysis, a confirmatory factor analysis (Kayapalı-Yıldırım and Ekinci, 2019; Naktiyok, 2019; Şencan, 2005) was performed, which enables the factor structure of the scale to be verified and the connection between existing variables and hidden variables to be determined. Confirmatory factor analysis is the factor analysis used to test the compatibility of the factors determined by explanatory factor analysis with the factor structures determined by the hypothesis. Explanatory factor analysis is used to test which variable groups are highly associated with which factor, while confirmatory factor analysis is used to determine whether the variable groups that contribute to the determined number of factors are adequately represented by these factors. Before performing a confirmatory factor analysis, values such as normality, multicollinearity, and sample size related to the distribution should be determined and the values reached should meet the reference values (Gürbüz and Şahin, 2014; Kline, 2005; Tavşancıl, 2014). For this reason, normality, multicollinearity, sample size analyzes were applied and the results obtained were compared with the reference values of RMSEA, SRMR, GFI, AGFI, NFI, $\chi 2$ / df, TLI and CFI fit criteria. While $>0.90$ is acceptable value for CFI, GFI, AGFI, NFI and TLI in confirmatory factor analysis, $>0.95$ is an extremely good value. For SRMR and RMSEA, $<0.1$ is an acceptable value, while $<0.05$ is considered an extremely good value (Gürbüz and Şahin, 2014; Kayapalı-Yıldırım and Ekinci, 2019; Marcoulides and Schumacher, 2001; Özdamar, 2017; Schumacher and Lomax, 2004; Seçer, 2015; Yildırım and Naktiyok, 2017).

The construct validity of the scale was performed with explanatory and confirmatory factor analyzes using two different samples. For the analysis, attention has been paid to the fact that the samples are composed of different individuals with similar characteristics. 
First, whether the data of both samples show normal distribution with multivariate, which is one of the assumptions of explanatory and confirmatory factor analyzes, was checked in R package program using Henze-Zirks Test, MVN, readxl packages and MVN, readxl libraries. As a result of the normality tests, it was found that both samples were multivariate normally distributed ( $\mathrm{p}(0.1846839,0.2134676)>0.05$, HZ1 test: 0.1725467 , HZ2 test: 0.18546254 and MVN: YES). Subsequently, explanatory factor analysis was performed for the construct validity of the scale and the results obtained are shown in Table-4. However, as a result of the analysis performed with explanatory factor analysis, four items (IM6, S1, EMC1 and EMC2 items) were removed from the scale due to the factor loadings being below 0.30 .

Table 4. Academic Success Inventory Scale Explanatory Factor Analysis Statistics

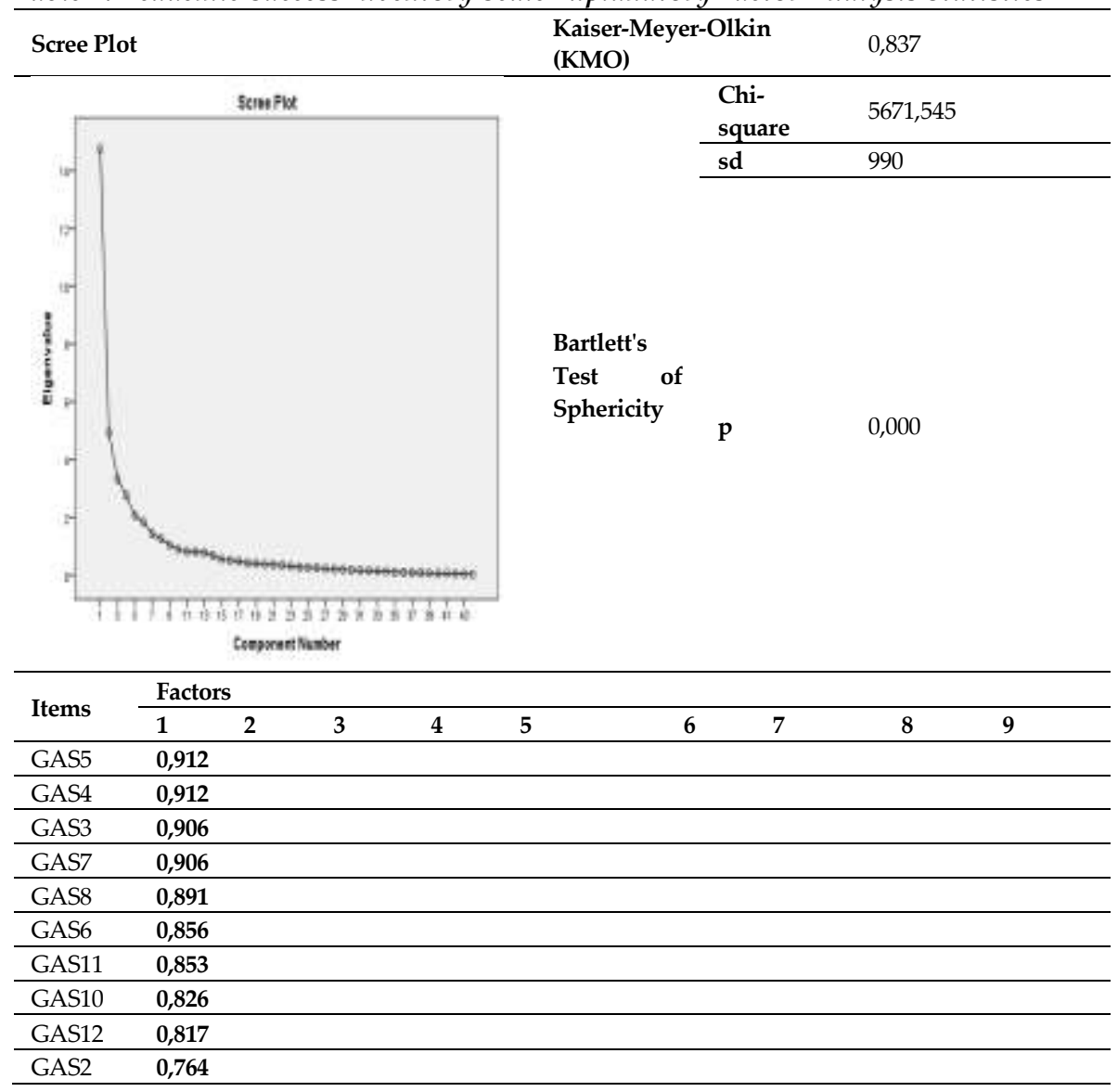




\begin{tabular}{|c|c|c|c|c|c|c|}
\hline GAS9 & 0,733 & & & & & \\
\hline GAS1 & 0,708 & & & & & \\
\hline IM1 & 0,688 & & & & & \\
\hline EMC3 & 0,599 & & & & & \\
\hline IM7 & 0,584 & & & & & \\
\hline IM2 & 0,531 & & & & & \\
\hline C3 & 0,403 & & & & & \\
\hline PIE2 & & 0,875 & & & & \\
\hline PIE3 & & 0,862 & & & & \\
\hline PIE5 & & 0,845 & & & & \\
\hline PIE1 & & 0,780 & & & & \\
\hline PIE4 & & 0,585 & & & & \\
\hline IM3 & & 0,806 & & & & \\
\hline IM8 & & 0,717 & & & & \\
\hline IM4 & & 0,686 & & & & \\
\hline IM5 & & 0,586 & & & & \\
\hline CD3 & & 0,417 & & & & \\
\hline PA3 & & & 0,892 & & & \\
\hline PA2 & & & 0,886 & & & \\
\hline PA1 & & & 0,851 & & & \\
\hline EM3 & & & 0,764 & & & \\
\hline EM1 & & & 0,740 & & & \\
\hline EM2 & & & 0,700 & & & \\
\hline EM4 & & & 0,685 & & & \\
\hline S3 & & & & 0,871 & & \\
\hline S4 & & & & 0,869 & & \\
\hline $\mathrm{S} 2$ & & & & 0,780 & & \\
\hline CD2 & & & & & 0,916 & \\
\hline CD1 & & & & & 0,896 & \\
\hline CD4 & & & & & 0,463 & \\
\hline LA1 & & & & & & 0,846 \\
\hline LA3 & & & & & & 0,769 \\
\hline LA2 & & & & & & 0,665 \\
\hline $\mathrm{C} 1$ & & & & & & 0,776 \\
\hline $\mathrm{C} 2$ & & & & & & 0,667 \\
\hline C4 & & & & & & 0.452 \\
\hline \multicolumn{7}{|c|}{ Total variance explained } \\
\hline Factors & Total & $\begin{array}{l}\% \\
\text { Variance }\end{array}$ & $\begin{array}{l}\text { \% } \\
\text { Cumulative }\end{array}$ & Total & $\%$ Variance & $\%$ Cumulative \\
\hline 1 & 14,811 & 32,914 & 32,914 & 14,811 & 32,914 & 32,914 \\
\hline 2 & 4,970 & 11,045 & 43,959 & 4,970 & 11,045 & 43,959 \\
\hline 3 & 3,452 & 7,671 & 51,630 & 3,452 & 7,671 & 51,630 \\
\hline 4 & 2,904 & 6,453 & 58,083 & 2,904 & 6,453 & 58,083 \\
\hline 5 & 2,076 & 4,614 & 62,697 & 2,076 & 4,614 & 62,697 \\
\hline 6 & 1,861 & 4,135 & 66,832 & 1,861 & 4,135 & 66,832 \\
\hline 7 & 1,426 & 3,170 & 70,002 & 1,426 & 3,170 & 70,002 \\
\hline 8 & 1,264 & 2,809 & 72,811 & 1,264 & 2,809 & 72,811 \\
\hline 9 & 1,056 & 2,348 & 75,158 & 1,056 & 2,348 & 75,158 \\
\hline
\end{tabular}


When the results of the explanatory factor analysis regarding the Academic Success Inventory for College Students Scale in Table 4 are examined, unlike the original scale of the scale, except for the "External Motivation/Current" dimension, it was seen that the 1st factor is "General academic skills", the 2nd factor is "Perceived instructor efficacy", the 3rd factor is "Internal motivation/confidence", the 4th factor is "Personal adjustment", the 5th factor is "External motivation/future", the 6th factor is "Socializing", the 7th factor is "Career decidedness", the 8th factor is "Lack of anxiety", the 9th factor is "Concentration". According to KMO value and results of Bartlett's Sphericity test, it was determined that the factor analysis is suitable for research data $(\mathrm{KMO}>0.80$ and $\mathrm{p}<0.05)$, the subscales of the scale have values in the range of $0.403-0.912$ for the 1 st subscale, $0.585-0.85$ for the 2nd subscale, $0.417-0.806$ for the 3rd subscale, $0.851-0.892$ for the 4 th subscale, $0.685-0.764$ for the 5 th subscale, It took values between $0.780-0.871$ for the 6th subscale, $0.463-0.916$ for the 7 th subscale, $0.665-0.846$ for the 8 th subscale and $0.667-0.776$ for the 9 th subscale (All factor loads $>0.30$ ), and that the variance of nine subscales explained the total variance by $75.158 \%$.

The conformity of the structure obtained after the explanatory factor analysis was checked by confirmatory factor analysis. In this context, the results of the confirmatory factor analysis made on the Academic Success Inventory for College Students Scale are given in Table 5.

Table 5. Academic Success Inventory Scale Goodness of Fit Values

\begin{tabular}{|c|c|c|c|c|c|c|}
\hline Fit criteria & Good fit & Acceptable fit & $\begin{array}{l}\text { Unrelated } \\
\text { model }\end{array}$ & $\begin{array}{l}\text { Single } \\
\text { factor } \\
\text { model }\end{array}$ & $\begin{array}{l}\text { 1th level } \\
\text { multi- } \\
\text { factor } \\
\text { Model }\end{array}$ & $\begin{array}{l}\text { 2nd } \\
\text { level } \\
\text { multi- } \\
\text { factor } \\
\text { Model }\end{array}$ \\
\hline RMSEA* & $0<R M S E A<0,05$ & $0,05 \leq R M S E A \leq 0,1$ & \multirow{4}{*}{$\begin{array}{l}\text { Values out- } \\
\text { side the ref- } \\
\text { erence lim- } \\
\text { its }\end{array}$} & \multirow{4}{*}{$\begin{array}{l}\text { Values } \\
\text { outside } \\
\text { the ref- } \\
\text { erence } \\
\text { limits }\end{array}$} & 0.075 & 0.085 \\
\hline$C F I^{*}$ & $0,97 \leq C F I \leq 1$ & $0,95 \leq$ CFI $\leq 0,97$ & & & 0.998 & 0.964 \\
\hline$T L I^{*}$ & $0,95 \leq$ TFI $\leq 1$ & $0,90 \leq$ TFI $\leq 0,95$ & & & 0.978 & 0.949 \\
\hline NFI & $0,95 \leq$ NFI $\leq 1$ & $0,90 \leq N F I \leq 0,94$ & & & 0.988 & 0.946 \\
\hline$\chi^{2} / \mathrm{df}$ & $<3$ & $<5$ & 5.127 & 3.214 & 2.220 & 2.379 \\
\hline
\end{tabular}

* RMSEA: Root Mean Square Error of Approximation; CFI: Comparative Fit Index; TLI: Tucker-Lewis Index; NFI: Normed Fit Index

It has been determined that the goodness of fit values of the unrelated model in Table 5 and the single factor model are outside the reference limits, and the goodness of fit values of the 1st and 2nd level multi-factor models 
are all within the reference limits. However, according to the values of goodness of fit, it has been determined that the 1st level multi-factor model is better than the 2nd level multi-factor model and it was evaluated that it would be appropriate to use the 1st level multi-factor model in the studies to be conducted in the social sciences area in relation to structural equation model in Turkey.

\section{Reliability Analysis of the Scale}

The reliability of the data collection tool was checked by calculating the internal consistency coefficient (Cronbach's alpha) for both the whole scale and all its sub-dimensions. The Cronbach's alpha coefficient is a measure of the internal consistency (homogeneity) of the items in the scale. In other words, it gives information about questioning whether the ' $k$ ' items in the scale form a whole in order to explain or question a homogeneous structure with alpha coefficient. Cronbach's alpha value takes a value in the range of $0-1$, and the closer this value is to 1 , the higher the reliability and internal consistency of the scale (Can, 2018; Karadeniz et al, 2019). Reference intervals of Cronbach's alpha internal consistency coefficient determined by Özdamar (1997) are in the form of " $0.00 \leq \alpha \leq 0.40=$ unreliable, $0.40 \leq \alpha \leq 0.60$ = low reliable, $0.60 \leq \alpha \leq 0.80$ = highly reliable, $0.80 \leq \alpha \leq 1.00$ = highly reliable". In this context, Cronbach's alpha coefficient values obtained in relation to nine sub-dimensions of ASICS consisting of 46 items are given in Table 6.

Table 6. Reliability Statistics

\begin{tabular}{llll}
\hline Item no & $\begin{array}{l}\text { Cronbach } \\
\text { Alpha } \\
\text { Coefficient Values }\end{array}$ & $\begin{array}{l}\text { Standardized } \\
\text { Cronbach Alpha } \\
\text { Coefficient Values }\end{array}$ \\
\hline The whole scale & 46 & 0,937 & 0,937 \\
\hline General academic skills subscale & 17 & 0,964 & 0,965 \\
\hline Perceived instructor efficacy subscale & 5 & 0,872 & 0,868 \\
\hline Internal motivation/confidence subscale & 5 & 0,751 & 0,772 \\
\hline Personal adjustment subscale & 3 & 0,898 & 0,898 \\
\hline Socializing subscale & 4 & 0,898 & 0,898 \\
\hline Career decidedness subscale & 3 & 0,837 & 0,846 \\
\hline Lack of anxiety subscale & 3 & 0,797 & 0,793 \\
\hline Concentration subscale & 3 & 0,789 & 0,793 \\
\hline
\end{tabular}


When the standardized / non-standardized Cronbach's alpha coefficient values in Table 6 were examined, it was seen that all values were above the reference value $(>0.70)$, and it was concluded that the scale is a reliable scale.

Item analysis should also be done regarding reliability. Item analysis is the operations performed to examine the contribution of the items in the scale to the scale. Within the scope of item analysis, evaluation is made according to the results obtained by calculating the values of "scale average when item is deleted", "scale variance when item is deleted", "corrected item whole correlation", "multiple correlation coefficient", "Cronbach alpha coefficient when item is deleted". ((1) Scale mean when the item is deleted: When the item is deleted, it is desired that there is no large variation in the averages. (2) Scale variance when the item is deleted: When the item is deleted, it is desired that there is no large variation in the values of the calculated variances. (3) Corrected Item Whole Correlation: It is desirable that this coefficient should not be negative and have values above 0.20-0.25. (4) Multiple Correlation Coefficient: It is desirable that the obtained value be quite high. Because the square of this coefficient is the coefficient of certainty and shows the percentage of the explanation of the dependent variable. (5) Cronbach alpha coefficient when the item is deleted: When an item is removed from the scale if the alpha coefficient is lower than the alpha coefficient calculated for the whole scale, that item should remain in the scale.) Values calculated within the scope of item analysis related to Academic Achievement Scale are given in Table 7.

Table 7. Item analysis statistics

\begin{tabular}{llllll}
\hline & $\begin{array}{l}\text { Scale average } \\
\text { when item is } \\
\text { deleted } \mathbf{( 1 )}\end{array}$ & $\begin{array}{l}\text { Scale } \\
\text { variance } \\
\text { when item is } \\
\text { deleted (2) }\end{array}$ & $\begin{array}{l}\text { Whole } \\
\text { correlation } \\
\text { of corrected } \\
\text { item (3) }\end{array}$ & $\begin{array}{l}\text { Multi- } \\
\text { correlation } \\
\text { coefficient } \\
\mathbf{( 4 )}\end{array}$ & $\begin{array}{l}\text { Cronbach's Alpha } \\
\text { Coefficient } \\
\text { when item } \\
\text { is deleted (5) }\end{array}$ \\
\hline GAS1 & 212,95 & 1945,075 & 0,742 & 0,785 & 0,933 \\
\hline GAS2 & 212,71 & 1952,208 & 0,642 & 0,831 & 0,934 \\
\hline GAS3 & 212,51 & 1942,221 & 0,700 & 0,935 & 0,933 \\
\hline GAS4 & 212,82 & 1932,880 & 0,710 & 0,916 & 0,933 \\
\hline GAS5 & 213,16 & 1936,927 & 0,737 & 0,897 & 0,933 \\
\hline GAS6 & 212,75 & 1938,051 & 0,747 & 0,884 & 0,933 \\
\hline GAS7 & 212,67 & 1941,665 & 0,725 & 0,947 & 0,933 \\
\hline GAS8 & 212,70 & 1929,173 & 0,775 & 0,906 & 0,933 \\
\hline GAS9 & 213,65 & 1935,329 & 0,636 & 0,808 & 0,934 \\
\hline GAS10 & 213,19 & 1938,141 & 0,666 & 0,853 & 0,933 \\
\hline GAS11 & 212,70 & 1941,855 & 0,686 & 0,885 & 0,933 \\
\hline
\end{tabular}




\begin{tabular}{|c|c|c|c|c|c|}
\hline & $\begin{array}{l}\text { Scale average } \\
\text { when item is } \\
\text { deleted (1) }\end{array}$ & $\begin{array}{l}\text { Scale } \\
\text { variance } \\
\text { when item is } \\
\text { deleted (2) }\end{array}$ & $\begin{array}{l}\text { Whole } \\
\text { correlation } \\
\text { of corrected } \\
\text { item (3) }\end{array}$ & $\begin{array}{l}\text { Multi- } \\
\text { correlation } \\
\text { coefficient } \\
\text { (4) }\end{array}$ & $\begin{array}{l}\text { Cronbach's Alpha } \\
\text { Coefficient } \\
\text { when item } \\
\text { is deleted (5) }\end{array}$ \\
\hline GAS12 & 212,55 & 1945,071 & 0,779 & 0,881 & 0,933 \\
\hline IM1 & 212,96 & 1912,177 & 0,780 & 0,821 & 0,932 \\
\hline IM2 & 213,72 & 1933,554 & 0,649 & 0,720 & 0,933 \\
\hline IM3 & 213,09 & 1973,309 & 0,493 & 0,788 & 0,935 \\
\hline IM4 & 213,14 & 1947,314 & 0,653 & 0,805 & 0,934 \\
\hline IM5 & 212,81 & 1999,211 & 0,324 & 0,587 & 0,936 \\
\hline IM7 & 212,80 & 1951,169 & 0,656 & 0,793 & 0,934 \\
\hline IM8 & 212,25 & 1998,327 & 0,532 & 0,755 & 0,935 \\
\hline PIE1 & 215,00 & 1963,132 & 0,487 & 0,731 & 0,935 \\
\hline PIE2 & 214,18 & 1983,237 & 0,375 & 0,873 & 0,936 \\
\hline PIE3 & 214,84 & 1994,074 & 0,329 & 0,840 & 0,936 \\
\hline PIE4 & 213,75 & 1997,427 & 0,348 & 0,584 & 0,936 \\
\hline PIE5 & 214,25 & 1993,183 & 0,327 & 0,781 & 0,936 \\
\hline $\mathrm{C} 1$ & 213,75 & 1993,850 & 0,362 & 0,726 & 0,936 \\
\hline $\mathrm{C} 2$ & 213,75 & 1957,598 & 0,558 & 0,721 & 0,934 \\
\hline $\mathrm{C} 3$ & 214,55 & 1954,668 & 0,554 & 0,582 & 0,934 \\
\hline $\mathrm{C} 4$ & 213,57 & 1962,617 & 0,517 & 0,567 & 0,937 \\
\hline EM1 & 212,83 & 1968,808 & 0,513 & 0,773 & 0,935 \\
\hline EM2 & 213,04 & 1946,332 & 0,651 & 0,880 & 0,934 \\
\hline EM3 & 213,11 & 1931,415 & 0,672 & 0,908 & 0,933 \\
\hline EM4 & 213,11 & 1938,438 & 0,642 & 0,805 & 0,934 \\
\hline S2 & 212,82 & 1989,030 & 0,377 & 0,813 & 0,936 \\
\hline S3 & 212,26 & 2022,148 & 0,257 & 0,840 & 0,936 \\
\hline S4 & 211,82 & 2044,116 & 0,312 & 0,728 & 0,937 \\
\hline CD1 & 212,67 & 2014,595 & 0,249 & 0,885 & 0,937 \\
\hline $\mathrm{CD} 2$ & 212,52 & 2014,779 & 0,274 & 0,886 & 0,936 \\
\hline CD3 & 213,18 & 2002,601 & 0,288 & 0,675 & 0,936 \\
\hline CD4 & 212,55 & 1995,227 & 0,409 & 0,719 & 0,935 \\
\hline LA1 & 215,67 & 2056,952 & 0,324 & 0,714 & 0,937 \\
\hline LA2 & 215,18 & 2060,121 & 0,314 & 0,775 & 0,936 \\
\hline$\overline{\mathrm{LA} 3}$ & 215,55 & 2022,420 & 0,268 & 0,781 & 0,937 \\
\hline PA1 & 213,30 & 2013,591 & 0,251 & 0,798 & 0,937 \\
\hline$\overline{P A 2}$ & 213,96 & 2005,851 & 0,250 & 0,835 & 0,937 \\
\hline PA3 & 214,03 & 2011,735 & 0,275 & 0,793 & 0,937 \\
\hline EMC3 & 212,65 & 1958,851 & 0,521 & 0,714 & 0,935 \\
\hline
\end{tabular}

When the item analysis statistics in Table 7 are examined, it has been determined that all values correspond to the reference values. Therefore, ASICS can be used in the form of 9 dimensions and 46 items. 


\section{Discussion, Conclusion and Recommendations}

In this study, it was aimed to adapt the Academic Success Inventory for College Students Scale into Turkish, to study its validity and reliability and to add it to Turkish literature. Original scale consists of 50 questions and ten subscales being 1. General Academic Skills, 2. Internal Motivation/Confidence, 3. Perceived Instructor Efficacy, 4. Concentration, 5. External Motivation/Future, 6. Socializing, 7. Career Decidedness, 8. Lack of Anxiety, 9. Personal Adjustment, 10. External Motivation/Current. The data used in this study were collected from students studying at two universities in Mersin province in July 2020 of the scale. As a result of the analysis, it was seen that the scale, unlike the original one, consists of 9 sub-dimensions and 46 items.

The Academic Success for College Students Inventory Scale will provide an alternative perspective to the measurement of academic achievement based on quantitative values that are dominant in national literature. Measurements based on academic achievement grade point average do not fully reveal students' interest, knowledge and orientation in certain courses. A measurement that includes qualitative conditions rather than grade point average can give better results in determining the academic success of students. This approach is expected to provide important data in evaluating both the academic performance of students and the effectiveness of educational institutions.

While academic achievement affects an individual's continuing education, professional career, social status, income, intellectual gains and social life, it is also a subject that influences the effectiveness of educational institutions, social welfare, economic development, technological innovation and socio-cultural development. As a matter of fact, the focus of national education policies and corporate education strategies is to increase the academic success of its students. In this context, it will enable the development of different perspectives to measure this issue, and the production of sound foresights and policies that will reinforce the practices. Test grade based measurement, which is widely used in the literature, does not fully reflect the academic development of the students. As a matter of fact, there are other factors that affect the academic development of students apart from lecture 
grades, and these factors should also be focused on in order to increase academic success. The Academic Achievement Inventory for College Students Scale has an important guiding feature in both academic studies and practical applications, as it takes these ignored points into account. Inclusion of the scale in national literature will contribute to the development of national literature and will be an important tool for practitioners. In particular, practitioners can make the necessary updates in educational activities by making a comprehensive evaluation according to the subscales of the scale.

The study has limitations due to its scope and content. The process of translating the scale from English to Turkish, applying the questionnaire only to students studying at four universities in Mersin province, data collection time and applied analysis techniques are the limitations of the study. Studies conducted on a sample of students studying at other universities may produce different results. Using the Academic Success Inventory for College Students Scale with other variables in the education system can be offered to researchers as a suggestion.

There are some limitations in this study. The study is limited to two universities in Mersin province, Mersin province where the research was conducted, the questionnaire form in which the data was collected and the study period, analysis methods used in the study.

\section{Kaynakça / References}

Alay, S. ve Koçak, S. (2003). Üniversite öğrencilerinin zaman yönetimleri ile akademik başarları arasındaki ilişki. Eğitim Yönetimi, 35, 326-335.

Alpar, R. (2012). Uygulamah istatistikve geçerlik-güvenirlik. Detay, Ankara.

Alver, B. (2005). Üniversite öğrencilerinin problem çözme becerileri ve akademik başarllarınn çeşitli değişkenlere göre incelenmesi. M.Ü. Atatürk Ĕ̆itim Fakültesi Eğitim Bilimleri Dergisi, 21, 75-88.

Alyılmaz, S. ve Polatcan, F. (2018). İetişim kurma istekliliği ölçeği: Bir ölçek geliştirme çalışması. Uluslararası Türkçe Edebiyat Kültür Ĕğitim Dergisi, 7(1), 447-458.

Ashkzari, M.K., Piryaei, S. ve Kamelifar, L. (2018). Designing a causal model for fostering academic engagement and verification of its effect on educational performance. International Journal of Psychology, 12(1), 136-161.

Brislin, R.W. (1970). Back-translation for cross-cultural research. Journal of Cross-Cultural Psychology, 1(3), 185-216. 
Can, A. (2018). SPSS ile bilimsel araştırma sürecinde nicel veri analizi. (6. Ed.), Pegem Akademi, Ankara.

Chamorro-Premuzic, T. ve Furnham, A. (2003). Personality predicts academic performance: Evidence from Two Longitudinal University Samples. Journal of Research in Personality, 37, 319-338

Daniels, L.M., Stupnisky, R.H., Pekrun, R., Haynes, T.L., Perry, R.P. ve Newall, N.E. (2009). A longititudinal analysis of achievement goals: from afective antecedents to emotional effects and achievement outcomes. Journal of Educational Psychology, 101(4), 948-963.

Davidson, W.B., Beck, H.P. ve Milligan, M. (2009). The college persistence questionnaire: development and validation of an instrument that predicts student attrition. Journal of College Student Development, 50(4), 373-390.

Deci, E.L., Vallerand, R.J., Pelletier, L.G. ve Ryan, R.M. (1991). Motivation and Education: The Self-Determination Perspective. Educational Psychologist, 26(3and4), 325-346.

Demir, Ö. ve Acar, M. (2020). Sosyal bilimler sözlüğü (7.b.). LiteraTürk, Konya.

Eygü, H. ve Güllüce, A.Ç. (2017). Determination of customer satisfaction in conservative concept hotels by ordinal logistic regression analysis. Journal of Financial Risk Management, 6, 269-284.

Eygü, H. veKılınç, A. (2019). Sosyo-ekonomik gelişmişlik algısı üzerinde etkili olan faktörlerin sıralı logit model yardımıyla araşırılması: Erzurum-Kayseri örneği. Journal of Academic Value Studies, 5(5), 1023-1040.

Festa-Dreher, D.V. (2012). The academic success inventory for college students: An item response theory analysis. Electronic Theses, Florida State University College of Education, USA.

Gadzella, B.M. (1994). Student-life stress inventory: Identification of and reactions to stressors. Psychological Reports, 74, 395-402.

Gürbüz, S. ve Şahin, F. (2014). Sosyal bilimlerde araştrrma yöntemleri felsefe-yöntemanaliz. (2. Ed.), Seçkin Yayınclık, Ankara.

Harackiewicz, J.M., Barron, K.E., Tauer, J.M. ve Elliot, A.J. (2002). Predicting success in college: A longitudinal study of achievement goals and ability measures as predictors of interest and performance from freshman year through graduation. Journal of Educational Psychology, 94(3), 562-575.

Howard, J.M., Nicholson, B.C. ve Chesnut, S.R. (2019). Relationships between Positive Parenting, Overparenting, Grit, and Academic Success. Journal of College Student Development, 60(2), 189-202. 
Kadim, M. ve Şişman, Y.A. (2017). Meslek Yüksekokulu Öğrencilerinin akademik başarı düzeylerinin karşılaştırılması. Uluslararası Yükseköğretimde Mesleki Eğitim ve Öğretim Sempozyumu, 12-14 Ekim 2017, Kahramankazan, 60.

Karadeniz, E., Koşan, L., Geçgin, E. ve Beyazgül, M. (2019). Üniversite öğrencilerinin finansal okuryazarlık düzeylerinin analizi: Kafkas Üniversitesi Sarıkamış Kampüsünde bir araştırma. CBÜ Sosyal Bilimler Dergisi, 17(2), 325-345

Kayapalı-Yıldırım, S. ve Ekinci, O. (2019). Siber mobbing ölçeği geçerlik ve güvenirlik çalışması. Mavi Atlas, 7(2), 294-320.

Kline, R. B. (2005). Principles and Practice of Structural Equation Modeling. (2. Ed.), Guilford Publications, Inc., NY.

Marcoulides, G. ve Schumacher, R. (2001). New developments and tecniques in structural equation modeling. Lawrence Erlbaum Associates, Publishers, London.

Naktiyok, S. (2019). Otel çalışanlarının örgütsel vatandaşlık davranışlarının iş performansı üzerine etkisi: Sivas ilinde bir uygulama. Journal of Tourism and Gastronomy Studies, 7(2), 1057-1076.

Neale, M.N. ve Liebert, R.M. (1980). Science and behavior: An introduction to methods of research. Prentice Hall International, Inc., London.

Nota, L., Soresi, S. ve Zimmerman, B.J. (2004). Self-regulation and academic achievement and resilience: A longitudinal study. International Journal of Educational Research, 41, 198-215.

Özdamar, K. (1997). Paket programlar ile istatistiksel veri analizi. Anadolu Üniversitesi Yayınları, Eskişehir.

Özdamar, K. (2017). Ölçek ve test geliştirme yapısal eşitlikmodellemesi ıbm spss, ıbm spss amos ve mintab uygulamalı. Eskişehir: Nisan Kitabevi.

Pallant, J. (2017). SPSS kullanma klavuzu spss ile adım adım veri analizi. (Trans. S. Balc, B. Ahi), Anı Yayınalık, Ankara.

Pintrich, P.R. (1999). Taking control of research on volitional control: Challenges for future theory and research. Learning and Individual Differences. Special Issue: Maintaining the Motivation to Learn, 11(3), 335-354.

Prevatt, F., Petscher, Y., Proctor, B.E., Hurst, A. ve Adams, K. (2006). The revised learning and study strategies inventory: An evaluation of competing models. Educational and Psychological Measurement, 66(3), 448-458.

Prevatt, F., Li, H., Welles, T., Festa-Dreher, D., Yelland, S. ve Lee, Jiyoon (2011). The academic success inventory for college students: Scale development and practical implications for use with students. Journal of College Admission, 26-31.

Pritchard, M.E. ve Wilson, G.S. (2003). Using emotional and social factors to predict student success. Journal of College Student Development, 44(1), 18-28. 
Rana, R.A. ve Mahmood, N. (2010). The relationship between test anxiety and academic achievement. Bulletin of Education and Research, 32(2), 63-74.

Robbins, S.B., Lauver, K., Le, H, Davis, D., Langley, R. ve Carlstrom, A. (2004). Do psychosocial and study skill factors predict college outcomes? A meta-analysis. Psychological Bulletin, 130(2), 261-288.

Ryan, R.M. ve Deci, E.L. (2017). Self-determination theory: Basic psychological needs in motivation, development, and wellness. Guilford Press, USA.

Sadeghi-Gandomani, H. ve Adib-Hajbaghery, M. (2018). Psychometric properties of Persian Version of academic success inventory for college students. Nursing and Midwifery Studies, 7, 174-179.

Saygın, M. ve Bekmezci, M. (2019). Mersin ilinde öğrenim gören üniversite öğrencilerinin girişimcilik eğilimleri: Devlet ve vakıf üniversitesi karşılaştırması. Toros Üniversitesi İISBF Sosyal Bilimler Dergisi, 6(11), 108-123.

Schumacher, R. ve Lomax, R. (2004). A beginner's guide to structual equation modeling. Lawrence Erlbaum Associates, Publishers, London.

Seçer, İ. (2015). Psikolojik test geliştirme ve uyarlama süreci spss ve hsrel uygulamaları. Anı Yayıncilık, Ankara.

Sheldon, K.M. ve Krieger, L.S. (2007). Understanding the negative effects of legal education on law students: A longitudinal test of self-determination theory. Personality and Social Psychology Bulletin, 33(6), 883-897.

Şencan, H. (2005). Sosyal ve davranışsal ölçümlerde güvenirlik ve geçerlik. Seçkin Yayınalık, Ankara.

Tabachnick, B. G. ve Fidell, L. S. (2001). Using multivariate statistic. (4. Ed.), Needman Heights. MA, Allyand Bacon.

Tavşanal, E. (2014). Tutumlarn ölçülmesi ve spss ile veri analizi. (5. Ed.), Nobel Yayınevi, Ankara.

Treffers-Daller, J. ve Milton, J. (2013). Vocabulary size revisited: T link between vocabulary size and academic achievement. Applied Linguistics Review, 4(1), 151-172.

Vaez, M. ve Laflamme, L. (2008). Experienced stress, psychological symptoms, self-rated health and academic achievement: A longitudinal study of swedish university students. Social Behavior and Personality, 36(2), 183-196.

Vallerand, R.J., Pelletier, L.G., Blais, M.R, Brière, N.M., Senécal, C. ve Vallières, E.F. (1992). The academic motivation scale: A measure of intrinsic, extrinsic, and amotivation in education. Educational and Psychological Measurement, 52, 10031017.

Weinstein, C.E. ve Palmer, D.R. (2002). Learning and study strategies inventory (IASSI): User's manual. (2. Ed.), Clearwater, FL, H and H Publishing. 
Yaşlığlu, M.M. (2017). Sosyal bilimlerde faktör analizi ve geçerlilik: Keşfedici ve doğrulayıc faktör analizlerinin kullanilması. Istanbul University Journal of the School of Business, 46(Special Volume), 74-85.

Ylldırım, F. ve Naktiyok, S. (2017). The mediating role of organizational support in the effect of transformational leadership on employee empowerment. Polish Journal of Management Studies, 16(1), 292-303.

York, T.T., Gibson, C. ve Rankin, S. (2015). Defining and academic success. Practical Assessment, Research, and Evaluation, 20(20), 1-20.

Zimmerman, B.J. (1990). Self-regulated learning and academic achievement: An Overview. Educational Psychologist, 25(1), 3-17.

Zwick, R. veSklar, J. (2005). Predicting college grades and degree completion using high school grades and sat scores: The role of student ethnicity and first language. American Educational Research Journal, 42, 439-464.

1.1 milyon öğrenci okulu bıraktı. (2019). SOZCU. January, 12, 2019. https://www.sozcu.com.tr/2019/ekonomi/1-1-milyon-ogrenci-okulu-birakti3092464/ (Access Date: 09.06.2020).

YOK ATLAS. (2020). Üniversitelerimiz. https://yokatlas.yok.gov.tr/universite.php (Access Date: 15.06 .2020$)$.

\section{Appendix}

Adaptation of Academic Success Inventory Scale for College Students to Turkish

\section{Genel akademik başarı}

1.1.Bu sene iyi bir çalışma programı uyguladım. (GAS5)

1.2.Bu sene gerçekten çok sıkı çalıştım. (GAS4)

1.3.Bu sene başarılı olabilmek için yapabileceğim her şeyi denedim. (GAS3)

1.4.Bu sene çok çalıştım. (GAS7)

1.5.Bu sene ders çalışma konusunda yeteneklerimi çok iyi kullandığımı düşünüyorum. (GAS8)

1.6.Bu sene çok sıkı çalıştım, çünkü bu senenin konularını anlamak istedim. (GAS6)

1.7.Bu sene ödevler konusunda çok iyiydim. (GAS11)

1.8.Bu sene hedef belirleme stratejisini kullandım. (GAS10)

1.9.Iyi hazırlandım. (GAS12) 
1.10.İyi bir not alabileceğimi ispatlamak için sıkı çalıştım. (GAS2)

1.11.Bu sene ajanda ve takvim gibi planlama araçlarını çok iyi kullandım. (GAS9)

1.12.Bu sene sınavlara hazırlanırken doğru konulara çalıştım. (GAS1)

1.13.Bu sene yeni konular öğrenmekten çok memnunum. (IM1)

1.14.Bu sene sadece öğrenmek uğruna öğrenme zorluğundan zevk aldım. (EMC3)

1.15.Bu sene notlarımın iyi olacağından oldukça emindim. (IM7)

1.16.Not ortalamamı korumak için bu sene iyi notlar almam gerekiyordu. (IM2)

1.17.Bu sene derslere odaklanmakta zorlandım.* (C3)

\section{Algilanan öğretmen etkinliği}

2.1.Öğretmen etkili olmadığ1 için zayıf aldım.*(PIE2)

2.2.Öğretmenim daha iyi olsaydı çok daha iyisini yapardım.*(PIE3)

2.3.Ne öğrendiysem, kendi çabamla öğrendim. Bu seneki derslerin öğretmenleri iyi değil.* (PIE5)

2.4.Öğretimin kalitesi beni hayal kırıklı̆̆ına uğrattı. ${ }^{*}$ (PIE1)

2.5.Bu seneki derslerin öğretmenleri daha iyisini yapmam için beni gerçekten motive etti. (PIE4)

\section{3. İçsel motivasyon/inanç}

3.1.Bu senenin derslerinin en zor konularını bile anlayabileceğimden emindim (IM3)

3.2.Bu senenin gerektirdiği beceri ve yeteneklere sahip olduğumdan oldukça emindim (IM8)

3.3.Bu senenin derslerinden A veya B alabileceğimden oldukça emindim (IM4)

3.4.Sıkı çalışsaydım, daha iyisini yapabilirdim (IM5)

3.5.Okuyacağım bölümü (Anadal) seçmekte çok zorlanıyorum.*(CD3)

\section{Kişisel düzenleme/durum}

4.1.Bu sene performansımı etkileyen bazı kişisel sorunlarım vardı (PA3) 
4.2.Hayatımdaki diğer problemlerle uğraşmak zorunda kalmasaydım bu sene çok daha başarılı olurdum.*(PA2)

4.3.Kişisel sorunlarımdan dolayı bu sene derslerimde başarılı olamadım.*(PA1)

\section{Diş motivasyon/gelecek}

5.1.Gelecekte başarılı olmam için bu sene çok önemli. (EM3)

5.2.İleride/gelecekte iyi bir işe girmek için bu derste başarılı olmak zorundaydım. (EM1)

5.3.Bu senenin kariyerime çok faydası olacak. (EM2)

5.4.Bu sene öğrendiğim konuları gelecekte gerçekten kullanacağımı düşünüyorum. (EM4)

\section{Sosyalleşme}

6.1.Çok fazla partiye/eğlenceye katıldığım veya dışarıda arkadaşlarımla takıldığım için sınıfta geri kaldım (S3)

6.2.Alkol kullanmak, bazen ders çalışmamı engelledi. ${ }^{*}(\mathrm{~S} 4)$

6.3.Faal bir sosyal hayatım olduğu için notlarım kötüye gitti.*(S2)

\section{Kariyer kararlılığı}

7.1.Mezun olduktan sonra hangi işi yapmak istediğimden eminim. (CD2)

7.2.Mezun olduktan sonra ne yapmak istediğimi biliyorum. (CD1)

7.3.Okuduğum bölümün tam bana göre olduğundan eminim. (CD4)

\section{Kaygısızlık}

8.1.Ne kadar iyi hazırlanmış olursam olayım sınavlar bende gerginlik yaratt. ${ }^{*}(\mathrm{LA} 1)$

8.2.Bu senenin sınavları beni endişelendirdi.*(LA3)

8.3.Bu sene beni endişelendirdi.*(LA2) 


\section{Odaklanma}

9.1.Bu sene derslerimde dalıp gitmemi engellemek çok kolaydı.(C1)

9.2.Bu sene derslere odaklanmakta zorluk yaşamadım.(C2)

9.3.Bu sene derslerde dikkatim çok kısa sürede dağıldı. ${ }^{*}(\mathrm{C} 4)$

Cevaplar: 7'li Likert (1= Kesinlikle katılmiyorum; $2=$ Kismen katılmıyorum; $3=$ Biraz katılmıorum; $4=$ Kararsızım; $5=$ Biraz katilıyorum; $6=$ Kısmen katiliyorum; 7; Kesinlikle katıliyorum)

* Tersten kodlanan ölçek maddeleridir.

\section{Kaynakça Bilgisi / Citation Information}

Orçanll, K., Bekmezci, M. and Boztoprak, H. (2021). Adaptation of academic success inventory scale for college students to Turkish: Validity and reliability study. OPUS-International Journal of Society Researches, 17(37), 3999-4026. DOI: 10.26466/opus.879645 